\title{
1. The establishment and development of the European Union and its trade policy Nicholas Perdikis and Laurie Perdikis
}

\subsection{INTRODUCTION}

The European Union (EU) is the world's largest trade bloc and currently consists of 28 member states, although this will decline to 27 when the United Kingdom (UK) withdraws its membership. It has a population of approximately 500 million citizens, which will decline by approximately 60 million as a result of the UK's departure following Brexit. With a gross domestic product (GDP) per capita of $€ 25,000$, the EU is one of the richest economies in the world although this varies between countries - ranging from 271 per cent of the average in Luxembourg, the richest, to 47 percent in Bulgaria, the poorest. In 2014 the EU traded approximately $€ 5$ trillion of exports and imports and is one of the most open, with a trade to GDP ratio of 34 per cent. It has also concluded 53 free trade agreements with other countries and is in negotiation to establish free trade arrangements with some of the largest economies in the world; notably the US via the Transatlantic Trade and Investment Partnership (TTIP), China and India. Its largest trading partners are the USA and China, accounting for 19 per cent and 10 per cent of its trade respectively. As a consequence of the structural changes to the world economy, with the rise of China and other emerging economies, the EU's share of world trade has declined from 19.5 per cent in 2004 to 16.5 per cent in 2014. Other established economies such as the US and Japan have also experienced similar falls. The EU's total trade has though increased over the same period, with exports rising by 80 per cent and imports by 65 per cent.

The purpose of this chapter is to trace the EU's evolution and how this has influenced and shaped its international economic relations. Domestic political and economic factors within the EU's member states and its enlargement have all played a significant role in shaping its international trade policy. They have inter alia had an important impact on the formulation and implementation of trade policy. The current decision by the British people to withdraw from the EU will likewise have an effect, not only on its composition but also the way its international trade policies evolve.

This chapter will begin with a short historical overview covering its inception as the European Coal and Steel Community (ECSC), its establishment as the European Economic Community (EEC) with the signing of the Treaty of Rome in 1957 and its eventual transmogrification into the EU. It will then proceed to discuss how the EU's development led it to initiate and in turn develop a common international trade policy. The chapter will conclude with a brief discussion of the future challenges facing the EU's trade policy. 


\subsection{CATALYSTS OF EUROPEAN ECONOMIC INTEGRATION}

Politics and economics have been the main catalysts for European integration (den Boer, 1993). Two devastating wars persuaded European politicians that national rivalries and the capacity for waging war amongst their nations had to be eliminated. The means to achieve this was through political and economic integration. Additionally it was perceived that this might also give Western Europe some independence from domination by the US on the one hand and the USSR on the other (Sidjanski, 2000; Jovanovic, 2005). Economic integration would deprive each European nation of the means to go to war with another, and intra-regional trade would also make these nations interdependent. Adam Smith in the Wealth of Nations had implied that nations that relied on one another for trade were unlikely to go to war (Smith, 1776 [1976]).

A further impetus for integration came from the US in the form of Marshall Aid, which required the European recipients to do two things. The first was to collectively draw up a reconstruction programme and the second was to agree the size of the aid package and how it was to be distributed amongst the recipients.

The Western European countries embraced these conditions and set up the Committee of European Economic Co-operation (CEEC), which drew up the European Recovery Programme. To cement economic integration, the Organisation for European Economic Co-operation (OEEC) was created in 1948. This tied the nations closer together in seeking common solutions to mutual economic problems.

These institutional arrangements provided a further impetus to Western European integration. The European Coal and Steel Community (ECSC) was established in 1951 and required France, Germany, Italy and the Benelux countries to pool the management of their coal and steel industries (Jovanovic, 2005).

A further catalyst came from developments in the theory of economic integration. Viner (1950) produced a path-breaking analysis on economic integration and its benefits to members participating in the formation of an economic bloc. This work emphasised the benefits and cost to a nation contemplating entering a customs union and/or free trade area and how to identify these theoretically. Viner's theory was based on partial equilibrium analysis (see Box 1.1). It attempted to identify the welfare effects resulting from the reduction of tariffs amongst member states while keeping them fixed against non-members, and the reallocation of production that this would bring about between the members. Countries integrating their economies would be assured of positive results if the trade between them increased while that with non-members was not diminished. In this way the world economy would also experience an increase in welfare. As long as trade creation exceeded trade diversion all would be well.

Viner's theory was further developed by others, in particular by Meade (1956) and Lipsey (1960). The former introduced the possibility of commodity substitution on the demand side and relaxing the idea of constant costs on the supply side. The work was still limited to partial equilibrium analysis which assumed the fixity of demand and supply curves - a factor that may not apply when tariff changes are not marginal. Nevertheless, this was a significant development in that it introduced the possibility that economic integration could affect the world price of goods that in turn would affect the consumption of both home- or bloc-produced goods and those produced in the rest of the world. In other words, bloc formation could be beneficial to non-bloc trade partners. 


\section{BOX 1.1 THE THEORY OF ECONOMIC INTEGRATION}

Whether a country benefits or not from joining an economic bloc depends on the potential benefits and costs in its accession. How these are measured, at least in theory, was developed by Viner (1950) and extended by others. Essentially the gains arise from reallocating resources from areas in which the country has a comparative disadvantage with its potential partners to those in which it has an advantage. The potential gains and losses can be summed up as the difference between the trade created by entering an economic bloc compared to the trade diverted away from those trading partners who do not become part of the bloc. The figures below can be used to illustrate this.

In Figure 1.1 we can see the market for goods and services in country A which is contemplating forming a free trade relationship with country $B$. The price of goods exchanged is measured on the vertical axis while the quantities are expressed on the horizontal axis. Country A's demand for goods and services is depicted by the downward sloping demand curve DA while domestic supply is shown by the upward sloping supply curve SA. Under autarky, where trade is totally restricted, the quantity of domestic goods bought and sold is $Q$ while the market price is PA. Let us assume that country A already trades with country $C$ which is able to supply it with as many goods and services as it wants at world prices. In other words country C's supply curve SC is horizontal. In the diagram we can see that world prices are PC, quantity demanded is $\mathrm{N}$, while domestic supply is $\mathrm{M}$. Compared to the autarkic situation, country A's domestic suppliers sell less - M - when set against to $\mathrm{Q}$, while consumers increase their consumption to $\mathrm{N}$ as a result in the decline in prices from PA to PC in the domestic market. Country C's producers now supply MN whereas under autarky nothing was supplied by foreigners. Trade has therefore been created between the partners. Trade creation is therefore $\mathrm{MN}$ and consists of a consumption effect $\mathrm{QN}$ and a production effect QM, as less efficient domestic production has been reduced and replaced by more efficient foreign production.

P.

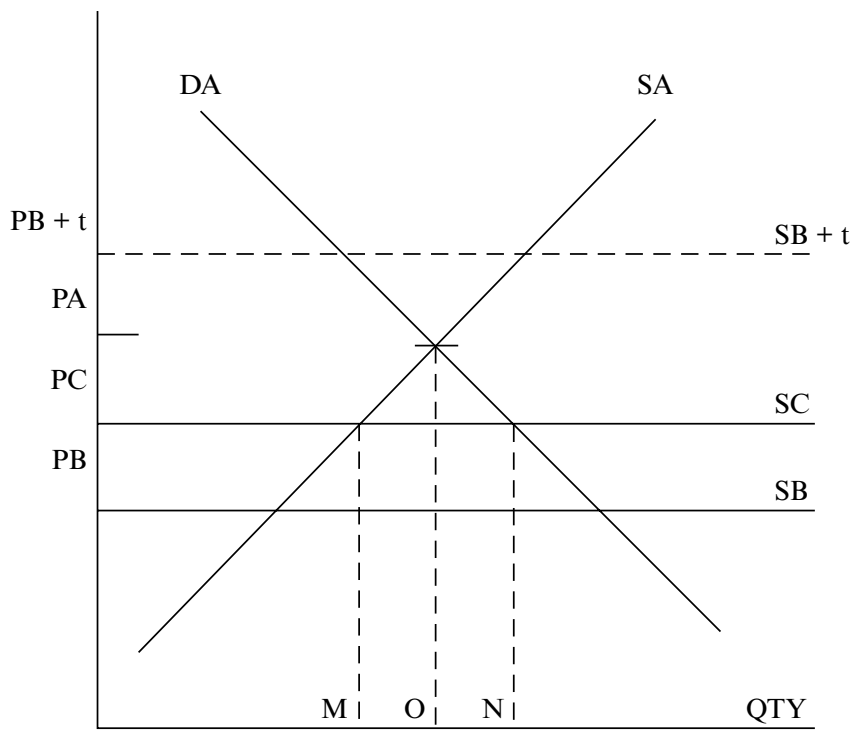

Figure 1.1 Customs union theory 
Figure 1.2 takes this analysis a little further and assumes that country $\mathrm{A}$ is already trading with country B which is more efficient than country $C$. This is illustrated by country B's supply curve being below that of country $\mathrm{C}$. In this situation country $\mathrm{B}$, even when a tariff is applied to its goods, out competes $C$ in country A's market. This is shown by the dotted horizontal supply schedule $\mathrm{SB}+\mathrm{t}$ which indicates that the supply curve $\mathrm{SC}$ has had a tariff applied to the goods that enter country A's market. With market prices PB+t ruling in A's market, MN is supplied by country B. If country A now decides to trade freely with country $C$ but keeps its tariff against country $B$, trade now moves in favour of $\mathrm{C}$. Looking at Figure 1.2 we can see that more trade has now been created as country C's products are now cheaper than B's or A's. Trade created as a result of this policy is now LM (as C's goods outcompete those produced by A) and NP as lower prices entice more consumers into the market. MN, the amount originally supplied by country $B$, is now totally diverted to $\mathrm{C}$.

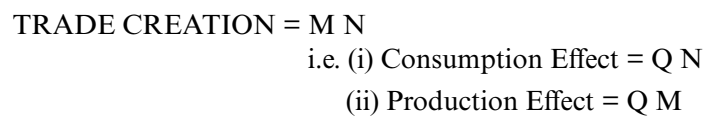

P.

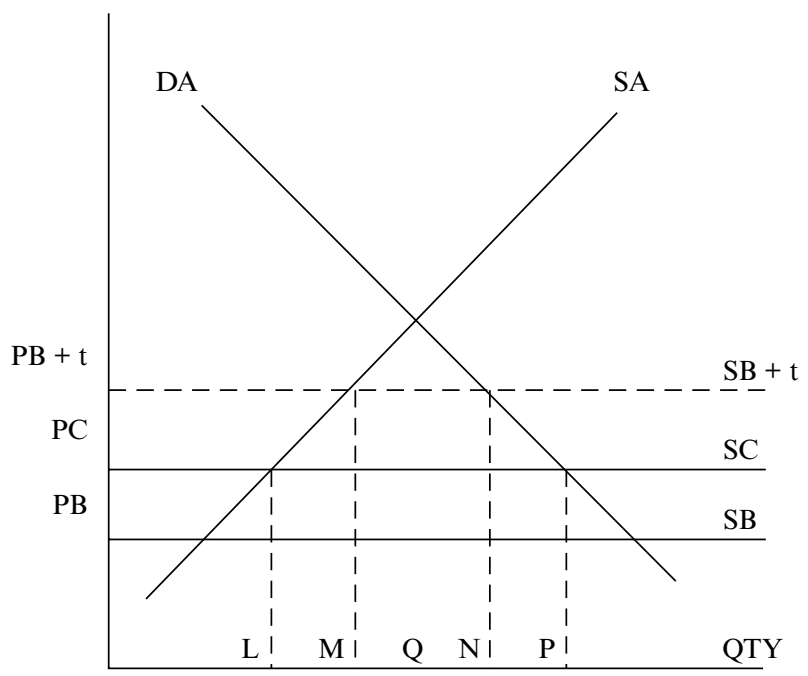

TRADE CREATION $=\mathrm{L} \mathrm{M}+\mathrm{N} P$

TRADE DIVERSION $=\mathrm{M} \mathrm{N}$

\section{Figure 1.2 Trade creation}

Figure 1.3 allows us to use the concepts just outlined to measure the costs and benefit to be derived by country $A$ in forming a free trade relationship with country $C$. Here we can see that consumer surplus (the gains accruing to consumers buying products at lower prices) has increased by $(e+g+f+k)$. Domestic producers have though seen a decline in the quantities they supply and the prices they receive for the remainder they sell. This is shown by space e. Country A's government has also seen a decline in its tariff revenues of $(f+h)$ as goods now enter tariff-free from $C$.

If the gains in consumer benefits $(e+g+f+k)$ are greater than the losses $(e+f+h)$ or $(g+k>$ $h)$ and the consumer and production benefits outweigh the losses to producers and the tariff revenue loss, then the formation of the customs union is beneficial to country $A$. 


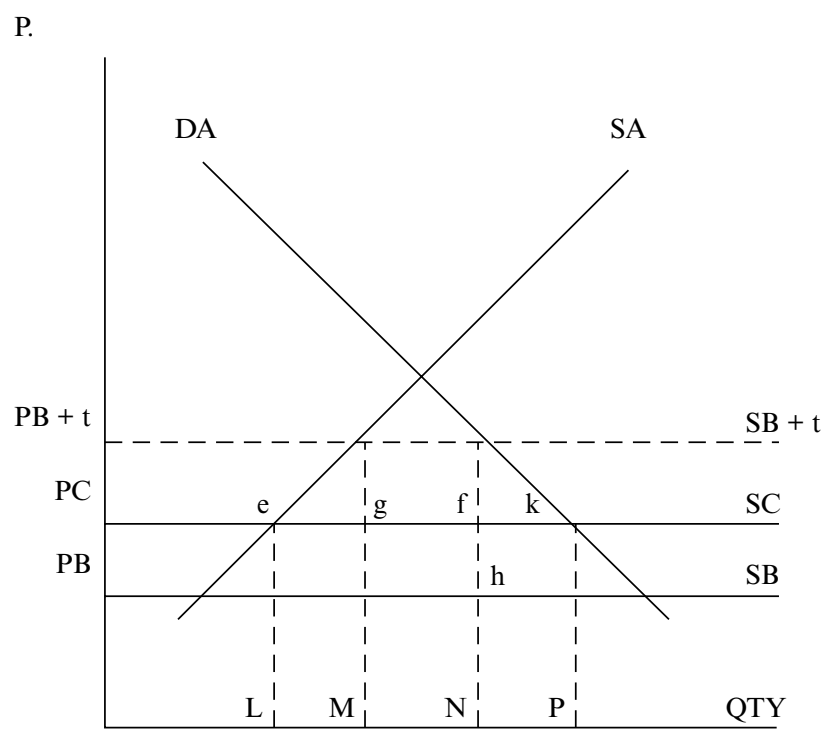

INCREASE IN CONSUMERS SURPLUS $=(\mathrm{e}+\mathrm{g}+\mathrm{f}+\mathrm{k})$

DECREASE IN PRODUCERS SURPLUS $=(\mathrm{e})$

DECREASE IN TARIFF REVENUE $=(\mathrm{f}+\mathrm{h})$

NET IMPACT $=(e+g+f+k)-(e+f+h)$

$=\mathrm{g}+\mathrm{k}-\mathrm{h}$

$(\mathrm{g}=$ PRODUCTION BENEFIT; $\mathrm{k}$ = CONSUMER BENEFIT $)$

$\therefore$ AS LONG AS g $+\mathrm{k}>\mathrm{h}$ THE FORMATION IS BENEFICIAL

Figure 1.3 Costs + benefits of customs union creation

Lipsey's (1960) work concentrated on the resource efficiency effects from the point of view of consumption. His analysis employed a modified general equilibrium framework. Using this analysis he was able to show that even a trade diversionary bloc could be welfare enhancing from a national and world perspective.

Viner (1950), Meade (1956) and Lipsey's (1960) theoretical analysis allowed economists to build up a picture of what should be considered by nations when contemplating economic integration. Their theoretical insights had a positive influence in clarifying the economic arguments for economic integration in Europe. As a result, the economic case for European integration was couched amongst the benefits to be gained from:

1. The gains from specialisation or the allocative effects;

2. The gains arising from economies of scale;

3. Gains arising to the bloc from improvements in its terms of trade with the rest of the world;

4. Improved efficiency from competition; 
5. Structural changes arising from bloc formation and its longer-term impact on the quality of labour, capital, technological change and entrepreneurship.

The theoretical work as well as impacting on the policy debate also influenced academic economists examining the ex-ante and ex-post impacts of bloc formation in Europe; in particular one can cite the work of Verdoorn (1954) and later Balassa (1967). These in turn showed what benefits might arise and what benefits did arise from the formation of the EEC.

\subsection{THE EUROPEAN ECONOMIC COMMUNITY AND THE TREATY OF ROME}

The experience gained by the participants in the OEEC and the ECSC had persuaded many, both in business and in government, that Western European economic integration should be taken a step further. The Belgian government proposed that industries allied to coal and steel such as transport and energy should also be pooled and brought under common control. This was agreed at Messina in 1955 and a new body was proposed to assume the functions of the ECSC and the OEEC to take this forward - namely, the EEC.

The Spaak report (Spaak, 1956) proposed a common market as the preferred form of Western European economic integration (see Box 1.2). It suggested that this common market should cover all industrial sectors bar atomic energy, for political reasons, for which a separate agreement would be necessary. The proposal to establish a common market would have far-reaching consequences for the development of a common trade policy.

The Spaak report and its proposals raised numerous doubts and fears amongst its recipients. France was concerned about the ability of its manufacturing sector to compete with Germany's once trade barriers were removed. Germany was concerned about the height of the proposed common external tariff (CET) to be applied to foreign goods coming into the common market from non-member states. It feared the impact of such a tariff on its firms and consumers buying goods from abroad and the possibility of retaliation from non-member states. France also wanted preferential access for its colonies into the market. The circle was squared by what has become commonplace in European negotiations, namely compromise. France was persuaded to accept a lower CET by having agriculture included in the agreement, and a common agricultural policy subsidising production via guaranteed prices. The CET was set by taking the average of the six nations' tariffs on the products included. It was also agreed that colonies and former colonies were to be granted preferential access to the EEC.

While the formation of a customs union would have a short-term trade diversionary effect on the EEC's trading partners, the longer-term implications could be very positive. For example, the domestic gains to be achieved from greater competition and structural changes as a result of this or allocative effects and the realisation of scale economies, the efficiencies to be gained in marketing and distribution, and the production of new goods, would lead to an increase in aggregate demand in the common market. Foreign exporters to the common market would benefit from this, as well as from a reduction in the risks and uncertainties arising from trading with countries with a CET. These more positive 


\section{BOX 1.2 TAXONOMY OF REGIONAL TRADE ARRANGEMENTS}

Economists usually identify four forms of regional trade arrangements (World Bank, 2000). These range from the most simple - the free trade area - to the customs union, the common market and ultimately the deepest form of integration, the economic union (Perdikis, 2007). As each additional step in the integration process is taken each individual country cedes some of its economic and political sovereignty to the group. In return it gains collective economic and political power vis-à-vis non bloc members and saves on the bureaucratic costs associated with administering and policing customs duties and individual trade policies.

\section{The free trade area}

Under this form participating nations remove explicit trade barriers such as tariffs and quotas between them but maintain their own individual trade policies against non-members. In other words, goods and services can be exchanged freely between the participants. Provisions are usually made via rules of origin to prevent goods coming into a country with lower barriers and being trans-shipped to members with higher trade barriers.

\section{The customs union}

The customs union is essentially a free trade area but one in which the participants agree to adopt a common set of trade barriers against non-members. This usually and most explicitly takes the form of a common external tariff (CET). By adopting a CET participating nations save on the resource costs involved in policing rules of origin.

\section{The common market}

This form of integration goes one step further than the customs union in that it allows the free movement not just of goods and services but also capital and labour. It is a deeper form of integration in that for the benefits to arise for the members it requires the harmonisation of domestic policies. If this were not the case the movement of capital and labour could be influenced by artificial differences in taxes and incentives between the member states.

\section{The economic union}

This is the deepest form of integration short of nations merging together to form a single state. As the name implies, large areas of economic and therefore political action between the participants are merged and dealt with by a single entity. While it is not necessary to have a common currency, the irrevocable fixing of exchange rates is required. In this way the competitiveness of each individual economy and its success is dependent on supply-side factors, and a lack of competitiveness cannot be dealt with by adjusting a nation's exchange rate. By adopting a common currency the bloc's firms can avoid the transaction costs involved in exchanging one currency into the other when carrying out inter-bloc trade.

effects would affect the attitudes of foreign companies and shape the way they influenced their governments.

The EEC was established by the Treaty of Rome in 1956 and its articles shaped and continue to shape the EU's trade policy and those of nations further afield. The Treaty set out the socio-political and economic aims and objectives of the EEC and the means by which those objectives were to be achieved. In economic terms it dealt with the improvement and enhancement of living standards and working conditions in general. It established a free trade area, a customs union and a common market, which led to the removal of internal barriers to trade in goods and services as well as the free movement 
of capital and labour. These are the so-called four freedoms. It also established a common commercial policy. In so doing it defined the economic relationship between the members and their direction of travel as well as its commercial relationships with its former colonies and non-member states.

\subsection{THE EUROPEAN UNION'S TRADE POLICY}

The preamble of the Treaty of Rome states that the then EEC and now EU will work towards international trade liberalisation (Article 131). The nature of the external trade policy is enshrined in the Common Commercial Policy set out in Article 133. Safeguard provisions are covered under Article 134 and Article 30, which protects the health of humans, animals and plants. It also protects national morals! Article 182 lays out the relationship between the EU and its former colonies, while Article 183 extends to them the same privileges as EU states. The relationships with states more recently associated with the EU come under Article 300, while authority is given to the EU to conclude agreements with international organisations under Article 310. Articles 301 and 60 grant the EU authority to impose sanctions on third countries. Recent sanctions against Russia have been carried out under the provisions in this article.

These articles define current EU trade policy and ensure that it covers any unilateral and bilateral agreements the EU may wish to undertake between sovereign nations or regional blocs. They also cover plurilateral agreements; for example, those reached with other members of organisations of which it is a member such as the WTO or the OECD. The articles also encompass the multilateral dimension - in other words agreements the EU reaches with other members of the WTO via its trade negotiations such as the Uruguay or the Doha round and as a participant in its activities, i.e. trade policy reviews, dispute settlement procedures, etc. They also allow the EU, on behalf of its member states, to apply commercial instruments such as countervailing duties, which act as safeguard mechanisms to prevent dumping and disruptive surges. They also enable the EU to challenge foreign governments' restrictions on its members' exports or their non-compliance with trade rules (Woolcock, 2011).

Two major factors have shaped and influenced trade policy over time. These are internal EU matters such as deepening and widening and international or external influences.

\subsubsection{The Influence of Deepening and Widening on EU Trade Policy}

The establishing of a Single European Market (SEM) by 1992 to capture the benefits arising from the harmonisation of national rules and regulations had a profound effect on the shaping of the Common Commercial Policy (CEC, 1985; Cecchini et al., 1988; Emerson et al., 1988; Pelkmans and Winters, 1988). Until this point national governments had responsibility for import quotas for textile products from developing countries via the Multi-fibre Agreement (MFA), and voluntary export restraints (VERs) on cars, electronic goods and machine tools. Empirical work suggests that as tariffs declined non-tariff barriers increased (see Winters, 1992 and references therein). The benefits expected to arise from the SEM changed all that. The removal of border controls on the movement of goods made national restrictions meaningless. In a 
similar way national economic strategies based on grants and subsidies, tax allowances and public procurement policies had to be harmonised and brought under EU rules. Similarly the opening of national financial markets and other services under the SEM also required EU coordination and adopted a 'rules'-based approach. All this ensured that in international trade negotiations the EU had rules and regulations in place which could be adopted by other nations.

The benefits to be derived from the SEM in terms of increased economic growth would ensure a larger market for those wishing to export to the EU. However the costs to various domestic sectors in individual countries might be mitigated by restricting foreign access to the SEM and leaving domestic firms to be the beneficiaries at the expense of foreigners. This was a fear held by both the US and Japan, which were, at this time, two of the EU's major trading partners (Yannopoulos, 1991; Woolcock, 1991; Ishikawa, 2012).

The potential benefits of the SEM to foreign nations increased the EU's economic power and allowed it to shape the agenda in international trade negotiations. The potential trade diversionary effects of the SEM also influenced non-member states' attitudes towards EU trade proposals and made them more likely to negotiate in order to retain access to the EU. They would want to share in the increase in demand for goods (CEC, 1988: 18-2). Conscious of the fears and suspicions of foreign countries that the EU was creating a 'Fortress Europe' the EU decided to negotiate more flexibly with its partners. Academic studies also raised questions about the potential benefits of 1992 and their impact on the EU's trading partners (Winters and Venables, 1991).

The EU's economic size in terms of population and GDP was further enhanced by a series of enlargements or widening that incorporated several European nations. There were several phases of enlargement, all of which involved some readjustment to the EU's external economic relationships. The first phase involved the accession of the UK and with it Denmark and Ireland in 1973. Those three countries had been members of the European Free Trade Area (EFTA), which in some respects had been an alternative to the EU (or the then EEC) for those countries that were unwilling to join it for economic or political reasons (the UK, Denmark, Ireland, Norway Sweden, Finland and Austria). As a result of the accession of the UK, Denmark and Ireland, the remainder negotiated a free trade arrangement with the EU involving manufactures.

The second phase of the expansion, or so-called southern enlargement, came with the accession of Greece in 1981 and Portugal and Spain in 1989. All three countries were keen to re-establish and enhance their democratic institutions by seeking and obtaining full membership after long periods of dictatorship. Enhancing their economic prospects by gaining access to a growing market was also an attraction from the point of view of business and the economy in general (Perdikis, 1980). While the southern expansion had little direct impact on the EU's wider trading relationships, the next phase of expansion taking in the so-called countries of the north did.

The formation of the European Economic Area (EEA) in 1994 ostensibly allowed the EFTA countries with the exception of Switzerland free access for goods and services and included the free flow of capital and labour. Essentially it extended the 'four freedoms' to EFTA countries. While this seemed attractive in that it allowed those countries free access to the largest market in the world, Austria, Finland, Norway and Sweden applied for full membership. Being allowed access to a club is one thing being allowed to write the rules is another! With the exception of Norway, whose citizens rejected their government's 
proposal in a referendum, all became full members in 1995. Norway's action and eventual trade agreement led to changes in the rules of engagement with the EEA.

The subsequent eastern enlargements after the fall of the Berlin wall came in two tranches in 1998 and 2000. The first involved the Czech Republic, Cyprus, Estonia, Hungary, Poland and Slovenia. The second dealt with Bulgaria, Latvia, Lithuania, Malta, Romania and Slovakia. These enlargements led to a change in the trading relationships the existing EU states had with their trading partners, but they also changed the relationships these countries had with the rest of the world. By becoming full members and accepting the Acquis Communitaire of the EU this meant that they adopted the CET and the trade policies of the EU towards non-member states (Gaisford et al., 2003).

From an empirical perspective the deepening and widening of the EU could be said to have been beneficial to the EU and its trading partners in terms of trade creation. Aitken (1973), Abrams (1980), Brada and Mendez (1985), Bayoumi and Eichengreen (1998), Holmes (2005) and Gil et al. (2008) are supportive of this view. Other more contradictory or partially supportive results come from Bergstrand (1985, 1989), Frankel et al. (1995), Soloaga and Winters (2001) and Dec and Gali (2003). While the former group found that there were some beneficial affects at some times, the latter group found that there were some negative and statistically significant effects.

The EU's experience in promoting and championing deep forms of economic integration also shaped its commercial policy. It encouraged other groups of nations to follow its example by removing barriers between them and establishing their own deeper forms of integration (Aggrawal and Fogarty, 2005; Woolcock, 2011). It encouraged this process by offering access to EU markets. It also pursued an agenda based on comprehensive trade policies through the WTO.

\subsubsection{International Factors and their Influence on the European Union's Trade Policy}

Market deepening and widening were not the only factors to shape EU trade policy. External or international factors have also played their part in influencing and shaping its trade policies. As a result it has responded to numerous pressures and changing priorities. These include tariff reductions, reform of the Common Agricultural Policy (CAP), the reduction in subsidies and state aids as well as rules on government procurement, intellectual property and investment; the so called TRIPS and TRIMS. All these issues forced the EU to reconsider its international trade policies.

Structural changes to the world economy and the rising power of the BRICS, and in particular China and India within that group, have also had a major influence on the strategic thrust of the EU's trade policy. Between 1994 and 2010 the BRICs' share of world trade grew from just over 6 per cent to approximately 16 per cent, and China became the world's largest exporter. It has been estimated, furthermore, that 90 per cent of the world's growth will take place outside of Europe over the next 10-15 years (2015).

Structural changes are not just confined to the rise of the contribution of the BRICS to world trade but also extend to what is traded. There has been a significant growth of world trade relative to world output. Between 1995 and 2008 the world's export to GDP ratio has grown from 20 per cent to 30 per cent. That growth has been accounted for significantly by trade in intermediate products (Ruta and Saito, 2014). This reflects the fact that the decline in trade barriers between countries, in particular over the last 20 years, 
allowed companies to produce final goods in one country but source their component parts in others. These supply chains have led to the growth of value added exports, from 15 per cent in 1995 to approximately 20 per cent in 2009. These global value chains (GVCs) mean that trade is now made up of multidimensional cross-border flows of intermediate goods, investment, services, know-how and people, and not just the flow of final goods (Ruta et al., 2013).

The combination of internal and external pressures caused the EU to develop what has been termed its 'comprehensive' trade policy, which it has applied towards its trading partners and the international organisations which underpin those relationships, such as the WTO. This thrust can be seen in the EU's Global Europe policy approach of 2006, the 2010 Trade, Growth and Jobs strategy, and more recently in the Trade for All policy (2015). The growing importance of trade to the EU can be seen in the growth of the number of jobs supported by the export of goods and services. This increased from 1 in 11 in 1995 to 1 in 7 by 2011. Consequently the Commission's role in trade negotiations has increased relative to that of the member states and this can be seen in the various amendments to the Treaty of Rome (Woolcock, 2011).

\subsubsection{The European Union's Multilateral Trade Relations}

From its inception the EU had to deal with trade issues on a multilateral basis. The original six were all signatories of the General Agreement on Tariffs and Trade (GATT), as were many of the countries that joined it during the various stages of enlargement. In the case of the former Central and Eastern European nations they had little experience of the GATT and its various trade liberalising rounds. In this way the EU provided a ready-made international trade policy that these countries could adopt on entry.

The Treaty of Rome stated clearly that the EU would engage in the multilateral trading system and participate fully with international bodies to achieve its goals. To this end it took a leading role in the numerous GATT rounds of trade negotiations. It adopted and implemented the outcomes of the Kennedy and Tokyo rounds that led to tariff reductions on manufactures, anti-dumping issues and non-tariff barriers (NTBs). It helped promote, shape and jointly lead with the US the Uruguay round of negotiations, which encompassed not only discussions on reducing tariffs and trade restrictions on manufactured goods but also involved trade in services, the protection of intellectual property rights and agriculture. Its drive for a rules-based system to deal with trade disputes led it to promote the disputes settlement procedure. This led to a major change in the way trade disputes were settled internationally moving away from a consensus-based approach to one based on rules. The EU would make use of this new system on several occasions to protect the trading interests of its member states. Along with the other participants, it was instrumental in the establishing the WTO; the body that now oversaw the GATT and the General Agreement on Trade in Services (GATS) as well as the other dimensions of international trade.

In the post-Uruguay-round world the EU pushed for a further and much more comprehensive set of trade negotiations. In particular it wished to discuss and implement a multilateral-rules-based approach towards competition policy, foreign investment, environmental provisions and public procurement standards. This agenda met with little support from developing countries or the US. The former were sceptical and believed that 
a new round would promote the interests of the developed countries at their expense. They were of the opinion that they had not gained much from the Uruguay round. This view was also prevalent amongst the non-governmental organisations (NGOs), which in turn questioned whether globalisation was distributing economic gains to poorer countries and their citizens. Their view was that the main beneficiaries were the developed countries, and multinational corporations in particular. The US was also cool on the idea and was in any case beginning to recast its traditional multilateral stance in terms of trade issues towards a more bilateral approach. As a result of these factors the Clinton administration turned against the idea, and the battle in Seattle in 1991 for a new trade round was lost.

With the 9/11 attacks on the Twin Towers in New York the US Bush administration decided to support the EU's position on a new trade round. The US view was that a new round was needed and geared more to the interests of developing countries. Its view was not wholly altruistic. The US believed improving the incomes of people in the developing would combat anti-US sentiment. For the EU the launching of the Doha round in 2001 was a political victory but one that came at a cost. It had to concede that developing countries could receive a waiver from the proposed TRIPS Agreement for the production of essential medicines. In order to get developing countries on board it also had to abandon most of the so-called Singapore issues it had promoted. These included transparency in public procurement, trade facilitation, and trade and investment rules and competition issues. The Doha round progressed at a snail's pace. This was not surprising given the conflict of interests between the negotiators and the terms of the round; namely that nothing was agreed until everything is agreed. The Bali package of 2013 was not the official end of the Doha round, but it probably is. While this may be the case, the Bali package did achieve some benefits in terms of market access and trade facilitation, development and food security, as well as some specific changes dealing with cotton and export subsidies in agriculture. The Nairobi meeting in 2015 also resulted in the signing of the Information Technology Agreement, which promoted trade in 11 products and is estimated to be worth $\$ 1.3$ trillion.

\subsubsection{The European Union's Bilateral Trade Relationships}

While the EU was deeply involved in multilateral trade negotiations and its priority was supporting the multilateral system, a debate began as to whether the EU's interests would be better served by a more active bilateral trade strategy. There were several reasons why this took place. The first was the EU's frustration with the slow progress of the Doha round and in particular in relation to the non-agricultural market access (NAMA) talks and services. Secondly, the US had shifted its emphasis away from multilateral negotiations towards bilateral trade deals with its major trading partners. Thirdly, the growing power of the transition economies, but in particular China, India, Brazil and South Africa as well as Russia - the BRICS - required a different policy approach in order to gain access to these growing economies. Fourthly, numerous countries were beginning to form trade blocs with their trading partners via preferential trade agreements that went beyond tariff and quota reductions and more towards deep integration. All of these developments required the EU to take stock of its then current strategy and engage with the new world order in a different way (Heydon and Woolcock, 2009).

Under pressure from the manufacturing and service sectors the EU began to explore 
the opening up of trade with emerging free trade areas. Several of the EU's existing trading partners had concluded agreements with a number of third parties that included TRIPS plus agreements, intellectual property rights, government procurement, investment rules, and environmental and labour protection. To meet these potential challenges to its economic interests the EU had to do the same.

To this end the EU has concluded a number of free trade agreements with the EEA countries Norway, Iceland and Switzerland. Essentially these countries have access to the single market but contribute to the EU's budget and accept the four freedoms. Other groups with which the EU has or is seeking free trade agreements include the Association of South East Asian Nations (ASEAN), the Andean Community, MERCOSUR and the Gulf Cooperation council (GCC). Individual countries include the US via the Transatlantic Trade and Investment Partnership (TTIP), Canada, Japan, India, Vietnam and Korea, as well as conducting tentative negotiations with China. The EU also has agreements with Mexico and Chile, which were put in place to limit the trade diversionary effects of their membership, and agreements with the North American Free Trade Area (NAFTA).

The EU also has several Economic Partnership Agreements (EPAs) with former North African colonies and other Middle Eastern countries. These Euro-Med agreements not only attempt to encourage free trade between them and the EU but also between the various signatories. These agreements include the Magreb countries of the west, such as Morocco, Algeria and Tunisia, and those in the Mashrek or east, which include Lebanon, Jordan and the Palestinian Authority. No agreement exists with Libya and that with Syria is currently suspended. A further agreement also exists with Israel.

Within Europe the EU has developed European Partnership Agreements (EPAs) with a number of Central and Eastern European states in an attempt to stabilise their economies and, inter alia, bring about political stability in a historically and more recently volatile part of Europe. These countries are principally the component states of the former Yugoslav republic and Albania. The agreements are really transition arrangements for these countries which will remain in force until they achieve the economic and political criteria necessary to become full members of the EU.

Although strictly a non-European state, Turkey also has an agreement with the EU in which it adopted the CET in 1995, and through which it gained free access to the single market for its manufactures. Whether Turkey will become a full member of the EU in the future is very much open to question. It too is sometimes not sure of its own position; sometimes it expresses a desire to join while at other times seeking greater ties with its neighbours to the east.

EPAs also exist with former colonies in Africa, the Caribbean and the Pacific (ACP). These agreements spring from the body of the Treaty of Rome. The original aim was to provide poor and developing countries and former colonies access to the then EEC for their goods on terms similar to those applying previously.

The original agreements were drawn up between the EU or EEC and the former colonies or Associated African States and Madagascar. The agreements granted access for these countries' goods and allowed for the gradual administration of tariffs, financial aid and guaranteed prices for tropical products in excess of world prices.

Two events changed this relationship between these colonies and the EU and the agreements associated with it. The first arose when with the passage of time more of them 
became independent and sought a different relationship. The second came from the accession of the UK in 1973. This event increased the number and geographical scope of the developing nations with which the EU had to deal. The UK had its own agreements with its former colonies in these areas and wanted to ensure that they were not discriminated against after its accession.

In dealing with the ex-colonies the EEC faced two views. France wanted a formalisation of its relationship with its former colonies while Germany and the Netherlands desired a non-discriminatory approach towards developing countries in general. The result was the Yaounde I (1964-69) and Yaounde II (1969-75) agreements, which extended the preferences mentioned above to 18 developing countries as well as giving them financial aid via the European Development Fund and access to the European Investment Bank.

With the UK's accession in 1973 the existing preferences it extended to its ex-colonies via Commonwealth preferences had to be accommodated. There was also a growing dissatisfaction within the EU and the developing nations with the operation of the Yaounde agreements. Two issues in particular required addressing. The first was the stabilisation of export earnings and the second was industrialisation. This led to a series of Lome agreements being established to cover these issues. The two new agreements established between 1975 and 2000 covered 46 developing countries. By Lome IV 70 developing countries were included and nearly 100 per cent of all goods produced by the ACPs had duty- and quota-free access to the EU. While this seemed generous it is sobering to consider that most ACP products would have entered the EU duty-free anyway. The rules only applied to products which the ACP countries currently produced and not those in which they might have developed a comparative advantage in the future. While these agreements increased the absolute level of exports from the ACP countries to the EU, they did not reverse the decline in their share of the EU's imports. The ACP countries' export success was hampered by structural issues, a lack of economies of scale, inadequate infrastructure and volatility in commodity prices. The STABEX fund designed to help stabilise commodity export earnings was beset with administrative problems such as delays in payments and bureaucratic procedures and so contributed little in the way of assistance.

The completion of the Uruguay round also impacted on the EU's relationship with the ACP countries since the agreement would end privileged access to the EU. This eventually resulted in the 2000 Cotonou agreement, which replaced Lome IV. The Cotonou agreement covered 71 ACP countries and was to run until 2020, but it has been replaced with the new style EPAs. Cotonou signalled a change in the EU's approach towards developing countries. It moved away from the stabilisation mechanisms of the STABEX and the more recent SYSIM and towards the active promotion of structural change and long-term development in these economies. The newer EPAs went a step further and made preferential access conditional on the application of human rights, democratic principles, the rule of law and good governance; for example a reduction in corruption.

\subsubsection{The European Union's Unilateral Trade Policies - the Generalised Scheme of Preferences (GSP)}

In parallel with the development of its policy towards the ACP countries the EU embarked on a unilateral trade policy towards developing countries that were outside of this group. The negotiations for a Generalised Scheme of Preferences (GSP) were 
initiated and promoted by the United Nations Committee on Trade and Development (UNCTAD). The negotiations aimed to promote the trade of developing countries and in so doing stimulate their economic growth and development prospects. In short they would also become less dependent on aid and loans. A further objective of the talks was to help the least developed countries neutralise the advantages gained by the richer developing countries that had acquired privileged access to the developed world.

The GSP applied to all developing countries and covered their manufactured and semi-manufactured products as well as processed agricultural products. Access to the scheme was limited to developing countries which essentially gave them an advantage over richer countries. The GSP operated by the EU lies outside the WTO GATT rules but is recognised by that body as a legitimate derogation. The provisions of the GATT do not require its signatories to offer GSP schemes. Their design and implementation is left up to each country. They can discriminate in the coverage of the goods included in their schemes and the size of the tariff preferences they offer the least developing countries.

The EU's original scheme was initiated in 1971 and modified on several occasions and currently applies to 176 developing nations. Between 2002 and 2005 the scheme was modified to include what became known as the GSP+. Under its current framework the EU offers three arrangements: the GSP, the GSP+ or to give it its formal title Special Incentive Arrangements, which provides added concessions for countries that adopt policies to support sustainability and good governance (see Van den Putte and Velluti, Chapter 12 in this volume), and a further special arrangement known as 'Everything but Arms' (EBA). Essentially, the GSP covers 7000 products or tariff lines. Of these 3300 are non-sensitive products. In other words their importation does not affect EU industries because either competition is deemed to be minor or they are not produced in the EU and as such they do not incur trade barriers. Sensitive products, which make up the remainder, are granted specific tariff reductions; for example, reductions of 3.5 per cent from Most Favoured Nation (MFN) ad valorum duties or 20 per cent for textiles and clothing products and 30 per cent for specific duties.

The GSP+ gives duty free entry to the most vulnerable developing countries on 6336 products. Vulnerability is defined by the World Bank's measure of poverty, non-diversity of exports and the share of EU GSP covered imports. To gain access to the GSP+ scheme countries have to sign up to and comply with 27 internationally agreed standards covering human rights, core labour standards and sustainable governance, as well as providing information on the legislation and measures taken relating to their implementation.

The EBA arrangements apply to all 50 least developed countries as defined by the United Nations and cover 7140 products. They are allowed to enter the EU duty free with the exception of arms and ammunition. A significant feature of this arrangement is that it has no expiry date nor is it subject to periodic review - factors that provide some stability for the least developed countries wishing to access the EU's privileges (Khorana et al., 2012).

\subsubsection{The European Union's Plurilateral Arrangements}

The EU has the authority to negotiate with sovereign nations on behalf of its member states with regard to specific trade issues of mutual interest. These negotiations are 
usually carried out under the aegis of one or other of the multilateral organisations. The EU for example has signed agreements on government procurement and trade in civil aircraft. More recently it signed the Information Technology Agreement (ITA) in Singapore in 1996 under the auspices of the WTO, although not all members were signatories. Similarly it has also concluded agreements on international investment rules brokered by the OECD. Currently the EU is negotiating a bilateral treaty based on the WTO's General Agreement on Trade in Services (GATS) with 23 other WTO members. This so-called Trade in Services Agreement (TiSA) will cover areas such as financial services, telecoms, e-commerce and maritime transport. It will also include the improvement of rules, licensing and the temporary international movement of professionals to provide services. Since 2014 the EU has engaged with another 17 members of the WTO to bring about an Environmental Goods Agreement (EGA). The aim is to eliminate tariffs on a range of environment-related products, including products that improve air and water quality, recycle and manage waste, contribute to energy efficiency, control air pollution and generate renewable energy. It is intended that the EGA will become a living agreement which would allow the addition of new products over time. By using the framework of the EGA, this would then reduce the need to establish new agreements.

\subsubsection{A New Direction in the European Union's Trade Policy?}

From the above we can see that the EU's trade policy is multidimensional and all encompassing. The EU has comprehensively taken over trade policy from the individual member states. As a significant world trading bloc this has required it to review, refine, clarify and document its approach to trade policy in the light of structural changes to the world economy. The EU's thoughts, aspirations and intentions were summarised and outlined in a new policy document in 2015 (see De Ville and Siles-Brügge, Chapter 13 in this volume). 'Trade for All: Towards a More Responsible Trade and Investment Policy' recognised the structural changes taking place in the world economy and the shifting of the centre of economic gravity towards Asia. It recognised in particular that future growth in trade would come from outside the EU. Specifically it recalibrates EU trade policy and emphasises a deeper engagement with the Far Eastern countries - in particular with China but also the economic blocs in that area. It suggests that the new realities regarding GVCs, which have developed as a result of trade liberalisation and globalisation, need to be taken on board and understood in the formulation of trade policy, for example by including agreements on domestic regulations, trade in services, the mobility of professionals, digital trade, etc., the often called 'behind-the-border' regulations.

The document also recognises that if trade policy is to engender not just economic growth but also wider development then it has to be about more than economics. As a result it clarifies policy aims with regard to EU small and medium sized enterprises and how policy will be geared to helping them access the benefits of trade. It also emphasises that trade liberalisation with other countries must not compromise EU ethical values and those recognised internationally as fundamental to human development and dignity. The document provides a broad agenda which the EU has to work through at a time of European and international economic flux. 


\subsection{CONCLUSION}

The purpose of this chapter was to provide a brief history of the EU and how its development has affected the implementation, development, application, nature and scope of EU trade policy. The chapter gave an account of the EU's deepening and enlargement and how these two events have impacted on its trade policy. It outlined the relevant articles in the Treaty of Rome that laid out the parameters of EU trade policy. In the separate sections dealing with the specifics of EU trade policy the chapter illustrated how this had changed over time in response to the shifting and evolving structural relationships in the world economy. In particular it dealt with the impact of the Uruguay and Doha rounds of trade negotiations and how these modified the EU's approach to multilateral and bilateral relations, looking at how the EU responded to changes in US trade strategy and the rise of the BRICS. While still aimed at opening up world trade, the EU has recognised that it must take account of the needs of domestic firms and in particular small and medium sized enterprises if it is to maximise the domestic benefits of trade. It also recognises that it can use trade policy to develop the broader interests of foreign peoples by promoting wider development goals such as human rights, good governance and sustainability.

As it moves forward deeper into the twenty-first century, the EU and its trade policy in particular will face new and unknown challenges. Its most immediate challenge will be dealing with the exit of the UK, or Brexit, from the EU. This will provide a particular challenge; while the vast majority of the UK's companies, both manufacturing and services, wanted to remain in the EU a majority of the electorate voted to leave. UK business needs stable access to the EU market, where it currently sends just over half of its exports of goods and services. To achieve access to the single market and 'passport' access for services would require under current EU conditions accepting the free movement of peoples and a contribution to the EU's budget. This Norwegian solution or 'Norwegian blue' might be acceptable to business but not to the wider electorate who do not wish to see unrestricted free movement. Finding a solution to this dilemma will prove particularly challenging for both the UK and EU. Will the UK have to sign a free trade agreement with the EU or will a compromise be found? Will the EU's insistence that access to the single market requires adherence to the principle of the free movement of labour mean that the UK opts for a trading relationship based on WTO rules? If the UK did secure an agreement that allowed it to have access to the single market without agreeing to the free movement of labour what impact would that have on other EU countries with growing Eurosceptic populations and parties? What impact would it have on Norway and Switzerland? Whatever happens in the negotiations, Brexit will have profound and far-reaching effects on the EU's trade policy. If the EU becomes too absorbed in dealing with the fallout from Brexit this could have an impact on its effectiveness in dealing with international trade issues.

For those who are engaged or wish to be engaged in EU trade policy research this is a very interesting and exciting time. For trade economists in particular there will be many areas of enquiry opening up. Not only will there be numerous trade issues that will need exploring as a result of Brexit, but the change in US trade policy under the Trump administration will provide plenty of material for discussion and analysis. As a consequence, it is likely that bilateral trade and plurilateral trade deals will become more the norm and provide new avenues of research. For the EU in particular, its potential bilateral trade 
deals with China and other countries in the Far East as well as India will also provide rich avenues of enquiry.

\section{SUGGESTED FURTHER READING}

Jovanovic, M.N. (2005), The Economics of European Integration: Limits and Prospects, Cheltenham, UK and Northampton, MA, USA, Edward Elgar Publishing.

Nello, S. (2009), The European Union, Economics, Policies and History, Maidenhead, McGraw-Hill.

Pelkmans, J. (2006), European Integration: Methods and Economic Analysis. Harlow, Prentice Hall.

Telo, M. (2001), European Union and New Regionalism, Aldershot, Ashgate.

Wilson, K. and van der Dussen, J. (1993), Europe and the Wider World, London, Routledge.

\section{REFERENCES}

Abrams, P.K. (1980), 'International Trade Flows under Flexible Exchange Rates', Federal Reserve Bank of Kansas City Economic Review, 65, 3-10.

Aggrawal, V.K. and E.A. Fogarty (2005), 'The Limits of Interregionalism: The EU and North America', European Integration, 27(3), 327-346.

Aitken, N. (1973), 'The Effects of EEC and EFTA on European Trade: A Temporal Cross-Section Analysis', American Economic Review, 63, 861-892.

Balassa, B. (1967), 'Trade Creation and Trade Diversion in the European Common Market', Economic Journal, 77, 1-21.

Bayoumi, T. and B. Eichengreen (1998), 'Is Regionalism Simply Diversion? Evidence from the Evolution of the EC and EFTA', in T. Ito and A.O. Krueger (eds), Regionalism versus Multilateral Trade Arrangements, Chicago, University of Chicago Press.

Bergstrand, J.H. (1985), 'The Gravity Equation in International Trade, Some Microeconomic Foundations and Empirical Evidence', Review of Economics and Statistics, 67, 474-481.

Bergstrand, J.H. (1989), 'The Generalised Gravity Equation, Monopolistic Competition and the Factor Proportions Theory in International Trade', Review of Economics and Statistics, 71, 143-153.

Brada, J.C. and J.A. Mendez. (1985), 'Economic Integration among Developed, Developing and Centrally Planned Economies: A Comparative Analysis', Review of Economics and Statistics, 67, 549-556.

CEC (1985), Completing the Internal Market, COM (85) 310, Brussels.

CEC (1988), Research on the 'Cost of Non-Europe': Basic Findings, Brussels.

Cecchini, P., with M. Catinat and A. Jacquemin (1988), The European Challenge 1992: The Benefits of a Single Market, Wilwood House, Aldershot.

den Boer, P. (1993), 'Europe to 1914, The Making of an Idea', in K. Wilson and J. van der Dussen (eds), The History of the Idea of Europe, London and New York, Routledge.

Dec, P. and J. Gali (2003), 'The Trade and Investment Effects of Preferential Trading Arrangements', National Bureau of Economic Research, Working Paper, 10160.

Emerson, M., M. Aujeans, M. Catinat, P. Goybet and A. Jacquemin (1988), The Economics of 1992: The E.C. Commission's Assessment of the Economic Effects of Completing the Internal Market, Oxford, Oxford University Press.

Frankel, J., E. Stein and S.J. Wei (1995), 'Trading Blocs and the Americas: The Natural, the Unnatural, and the Super-natural', Journal of Development Economics, 47, 61-95.

Gaisford, J.D., W.A. Kerr and N. Perdikis (2003), Economic Analysis for EU Accession Negotiations: Agri-food Issues in the EU's Eastward Expansion, Cheltenham, UK and Northampton, MA, USA: Edward Elgar Publishing, 2004.

Gil, S., R. Llorca and J.A. Martinez-Serrano (2008), 'Assessing the Enlargement and Deepening of the European Union', World Economy, 39, 1253-1272.

Heydon, K. and S. Woolcock. (2009), The Rise of Bilateralism: Comparing American, European and Asian Approaches to Preferential Trade Agreements, Tokyo/New York, United Nations Press.

Holmes, T. (2005), 'What Drives Regional Trade Agreements that Work?', HEI Working Paper, 07.

Ishikawa, K. (2012), Japan and the Challenge of Europe 1992, London, Bloomsbury.

Jovanovic, M.N. (2005), The Economics of European Integration, Limits and Prospects, Cheltenham, UK and Northampton, MA, USA: Edward Elgar Publishing. 
Khorana, S., M.T. Yeung, W.A. Kerr and N. Perdikis (2012), 'The Battle over the EU's Proposed Humanitarian Trade Preferences for Pakistan: A Case Study in Multifaceted Protectionism', Journal of World Trade, 46(1), 33-59.

Lipsey, R.G. (1960), 'The Theory of Customs Unions: A General Survey', Economic Journal, 63, 33-49.

Meade, J.E. (1956), The Theory of Customs Unions, North Holland.

Pelkmans, J. and L.A. Winters (1988), Europe's Domestic Market, Chatham House Papers 43, RIIA/Routledge.

Perdikis, N. (1980), 'Concentration and Foreign Domination in the Greek Manufacturing Sector' in F. Dechene (ed.) The Mediterranean Challenge: IV. The Tenth Member-Economic Aspects, Sussex European Research Centre, University of Sussex, Brighton.

Perdikis, N. (2007), 'Trade Arrangements, Depth of Integration', in W.A. Kerr and J.D. Gaisford (eds), Handbook on International Trade Policy, Edward Elgar Publishing, Cheltenham, UK and Northampton, MA, USA.

Ruta, M. and M. Saito (2014), 'Chained Value', Finance and Development, 51(1).

Ruta, M., M. Saito and J. Turunen (2013), 'Trade Interconnectedness: The World with Global Value Chains', IMF, Washington.

Sidjanski, D. (2000), The Federal Approach to the European Union or the Quest for an Unprecedented European Federalism, Ann Arbor, University of Michigan Press.

Smith, A. (1776), An Inquiry into the Nature and Causes of the Wealth of Nations, reprinted in W.B. Todd (ed.) (1976), Glasgow Edition of the Works and Correspondence of Adam Smith, vol. I, Oxford, Oxford University Press.

Soloaga, I. and L.A. Winters (2001), 'Regionalism in the Nineties: What Effect on Trade?' North American Journal of Economics and Finance, 91, 1-29.

Spaak, P-H. (1956), Spaak Report, https://www.cvce.eu/en/obj/the_spaak_report-en-4b911a0a-6bd0-4e88-bff94c87690aa4e8.html

Verdoorn, P.J. (1954), 'A Customs Union for Western Europe - Advantages and Feasibility', World Politics, 6, 482-500.

Viner, J. (1950), 'The Customs Union Issue', Carnegie Endowment for International Peace.

Winters, L.A. (1992), 'The European Community: A Case of Successful Integration?' Paper no. 11 presented to the World Bank and CEPR Conference on New Dimensions in Regional Integration, Washington DC, April 1992.

Winters, L.A. and A. Venables (1991), European Integration: Trade and Industry, Cambridge, Cambridge University Press.

Woolcock, S. (1991), Market Access Issues in EU-US Relations: Trading Partners or Trading Blows? London, Pinter.

Woolcock, S. (2011), 'Trade Policy', in H. Wallace, M.A Pollack and A.R. Young (eds), Policy Making in the European Union, Oxford, Oxford University Press.

World Bank (2000), Trade Blocs, World Bank Policy Research Report, Oxford, Oxford University Press.

Yannopoulos, G. (ed.) (1991), Europe and America, 1992: US-EC Economic Relations and the Single European Market, Manchester, Manchester University Press. 